\title{
IMPAIRED TH1-RELATED IMMUNE SYSTEMS IN CANCER PATIENTS
}

\author{
Katsuaki Uno'. ${ }^{2}$, George Hosokawa', Shizuko Chikumaru', \\ and Kyoji Ogoshi ${ }^{2}$ \\ Comfort Hospital, Yokohama, Japan' \\ Department of Surgery, Tokai University, Kanagawa, Japan ${ }^{2}$ \\ (Received on Mar. 10.2000, accepted on June 19, 2000)
}

Key Words: Cancer patients; immune systems.

Subjects: Cancer patients.

Abbreviations: IL-12 = Interleukin-12;TNF $\alpha=$ tumor necrosis factor-alpha; INF $\gamma$ interferon-gamma; $\mathrm{Th}=$ helper $\mathrm{T}$ cell subjects; $\mathrm{NK}=$ natural killer.

\section{Abstract}

In order to evaluate the influence of Thl-related cytokines on disease progression, the levels of interleukin-12 (IL-12), interferon-gamma (INF- $\gamma$ ) and tumor necrosis factor-alpha (TNF- $\alpha$ ), helper T cell (Th) subsets, and natural killer (NK) cells were examined in 337 Japanese patients with histologically confirmed primary adenocarcinomas of the stomach and colorectal and in 172 control subjects.

Levels of IL-12, IFN- $\gamma$, TNF- $\alpha$, and Thl cells were significantly lower in cancer patients than those in the control group. On the other hand, levels of Th2 cells and NK cells were significantly higher in cancer patients than those in the control group. Th1related cytokines were suppressed even in early-stage patients. Results of the present study suggest that Th1-related immune parameters were suppressed in cancer patients, even in early-stage patients, and that they were useful as immunological markers for detecting groups of patients at high risk for cancer.

\section{Introduction}

It is still difficult to discover early-stage cancers, though preventive medicine has become more important. Conventional methods, including hematological, biochemical, and urinary examinations as well as X-rays, are not sensitive enough to detect cancers at an early stage. The development of better techniques for detecting cancer is desired. Comparative studies of $\mathrm{Th} 1$ and $\mathrm{Th} 2$ subsets have revealed that IFNgamma (IFN- $\gamma$ ) and tumor necrosis factor-alpha (TNF- $\alpha$ ) produced by Thl cells and interleukin-12 (IL-12) by antigen-presenting cells (APC) through cross-talk between these cells is a key factor for the differentiation of Th cells into Thl cells which are 
responsible for cancer immunity (Brunda, Luistro et al., 1993; Cassatella, Meda et al., 1995; Chan, Kobayashi et al., 1995). Both cytokines seem to modulate and optimize the immune responses, including anti-tumor responses, originally initiated in an antigenspecific or non-specific manner (Zou, Yamamoto et al., 1995).

In order to evaluate the influence of Th1-related cytokines on disease progression, the levels of IL-12, INF- $\gamma$ and TNF- $\alpha$, Th subsets, and Natural Killer (NK) cells were examined in patients with primary adenocarcinomas of the stomach and the colorectal and in normal healthy subjects.

\section{Patients and Methods}

Three-hundred and thirty-seven Japanese patients diagnosed between November 1, 1998 and May 31, 2000 with histologically confirmed primary adenocarcinomas of the stomach and the colorectal were included in the present study. Their ages ranged from 14 to 85 years (mean: 57 years), and $58.8 \%$ were men. Their characteristics are shown in Tables I and II. Cancer patients were classified by means of TNM classification [International Union Against Cancer (UICC) (1997)], into the following groups: a T1group, whose tumors were limited to invasion of the mucosa or the submucosa; earlystage groups; a T2-T4 group, whose tumors invaded proper muscle (T2, T3, and T4); and an advanced-stage group (T-factor). One hundred seventy-two individuals, aged 27-80, in whom no abnormal findings were revealed by blood chemistry or upper- and lowergastrointestinal examinations, were enrolled as normal healthy controls. Informed consent was obtained from all individuals.

Heparinized peripheral blood cells were diluted with phosphate buffered saline without calcium or magnesium (PBS (-)). Centrifuged on Ficoll-Conray at $x 400 \mathrm{G}$ for 20 min, mononuclear cells were then collected. After being washed, mononuclear cells were resuspended in RPMI-1640 (IBL, Co., Fujioka, Gunma, Japan) with 10\% FCS (Cancera, Rexdale, Ont.) at a concentration of $1 \times 10^{6}$ cells $/ \mathrm{ml}$ of lymphocytes. Lymphocytes $\left(2 \times 10^{5} / 200 \mu \mathrm{l}\right)$ and $20 \mu \mathrm{g} / \mathrm{ml}$ of phytohemagglutinin P (PHA-p; Difco, Laboratories, Detroit, MI) were added to 96 holes micro titer plates, to yield $220 \mu \mathrm{l}$ in final volume.

After incubation at $37^{\circ} \mathrm{C}$ for 24 hours with $5 \% \mathrm{CO}_{2}$, supernatants were collected for cytokine assay. IL-12 was measured by an enzyme linked immuno solvent 
assay (ELISA) kit (R\&D Systems, Minneapolis, MN). IFN- $\gamma$ and TNF- $\alpha$ were measured with ELISA kits (IFN- $\gamma$ : Biosource, Nivelles, Belgium; TNF- $\alpha$ : JIMRO, Gunma, Japan). All cytokines were measured according to the manufacturers' instructions.

For identification of Th cell subsets, heparinized peripheral blood cells were stimulated with $25 \mathrm{ng} / \mathrm{ml}$ of Phorbol 12-Myristate 13 acetate (PMA; Sigma Chemical Co., St. Louis, MO), $1 \mu \mathrm{g} / \mathrm{ml}$ of lonomycin (Sigma Chemical Co., St. Louis, MO) and $10 \mu \mathrm{g} / \mathrm{ml}$ of Brefeldin-A (Sigma Chemical Co., St. Louis, MO) at $37^{\circ} \mathrm{C}$ with $5 \% \mathrm{CO}_{2}$ for 4 hours. $300 \mu \mathrm{l}$ of stimulated blood was added to $20 \mu \mathrm{l}$ of peridinin chlorophyll protein (percept)-conjugated anti-CD4 antibody (Immunotech, Marseille, France) and incubated at room temperature for 15 min. $4 \mu$ l of x 10 Lysing Solution (BDIS, San Jose, CA) was added and this solution was incubated for fixing cell surface epitopes, lysing red blood cells and pretreatment for permialization. Then $1.5 \mu \mathrm{l}$ of permializing solution (BDIS, San Jose, CA) was added and the solution was incubated at room temperature for $10 \mathrm{~min}$. For staining of intracellular cytokines, $20 \mu \mathrm{l}$ of fluorescein isothiocyanate (FITC)-conjugated anti-IFN- $\gamma$ antibody (BDIS, San Jose, CA) and phycoerythrin-conjugated anti-IL-4 antibody (BDIS, San Jose, CA) were added and this solution was incubated for 30 minutes at room temperature. FITC-conjugated IgG2a/PE-conjugated IgG1 antibodies (BDIS, San Jose, CA) were used as negative controls. The FACS analysis was performed with a FACScan (BDIS, San Jose, CA).

For the assay of NK cell activity, target cells (K-562) $3 \times 10^{6}$ were incubated with $100 \mu \mathrm{Ci}$ of ${ }^{\mathrm{SI}} \mathrm{Cr}$-sodium chromate (Diichi Radioisotope, Tokyo, Japan) at $37^{\circ} \mathrm{C}$ for 1 hour. After being washed, $0.1 \times 10^{5} / 10 \mu$ l of the target cells were mixed with $1 \times 10^{6} / 200$ $\mu \mathrm{l}$ of the effector cells. After incubation at $37^{\circ} \mathrm{C}$ for 3.5 hours, the supernatant was collected and its radioactivity measured. NK cell activity was calculated by means of the following formula.

NK cell activity $(\%$ lysis $)=($ test $\mathrm{cpm}-$ spontaneous $\mathrm{cpm}) /($ total $\mathrm{cpm}-$ spontaneous $\mathrm{cpm})$

The analyses were performed with a commercially available statistical package (SPSS Ver 10.0). We used Mann-Whitney U and Kruskal-Wallis tests for the comparison. A result was considered significant when the $\mathrm{p}$ value was less than 0.05 . 


\section{Results}

Among normal healthy controls, levels of IL-12, INF- $\gamma$, TNF- $\alpha$, and Th1 were significantly higher than those in cancer patients, while levels of Th2 and NK cell activity in normal healthy controls were lower than those in cancer patients (Table III).

Levels of IL-12, INF- $\gamma$, TNF- $\alpha$, and Thl in normal healthy controls were significantly higher than those in patients with early-stage gastric cancer, while NK cell activity in normal healthy controls was significantly lower than that in cancer patients. Levels of IL-12, INF- $\gamma$, and Th1, and NK cell activity in normal healthy controls were also significantly higher and lower, respectively, than those in patients with early-stage colon and rectal cancer. In the advanced-stage gastric and colorectal cancers, similar results were obtained. Levels of NK cell activity in patients with colon cancers differed significantly between those with early-stage and those with late-stage cancers. Between gastric and colorectal cancers there was no significant difference even when early-stage and advanced patients were compared (Table IV).

\section{Discussion}

IL-12, IFN- $\gamma$ and TNF- $\alpha$ are known to induce proliferation and differentiation of Th1 cells (Cassatell, Meda, et al., 1995). These Th1-related cytokines are shown to negatively modulate the growth of tumors. In animal models, Thl cells have been shown to be activated shortly after the implantation of tumor cells and to exert anti-tumor effects, but these activities were suppressed and overwhelmed by expanding $\mathrm{Th} 2$ cells as tumor cells grew (Zou, Shimizu et al.,1992).

Our results demonstrated that levels of mitogen-induced Th1-related cytokines (IL-12, IFN- $\gamma$, TNF- $\alpha$ ) and those of Thl subsets were significantly lower in cancer patients than those in the normal healthy control group, while that of the Th2 subset and NK cell activity was higher in cancer patients compared to those in the control group. Among early- and advanced-stage cancer patients, there was no difference between these levels, except levels of NK cell activity in those with colon cancer.

Due to previous studies of Th1 and Th2 subsets (Gately, Desai et al.,1991; Mosmann, Cherwinski et al., 1986), the mechanism of the positive interaction between IL-12 and IFN- $\gamma$ for Th1 induction has been defined (Chen, Kobayashi et al., 1997; Sen, 


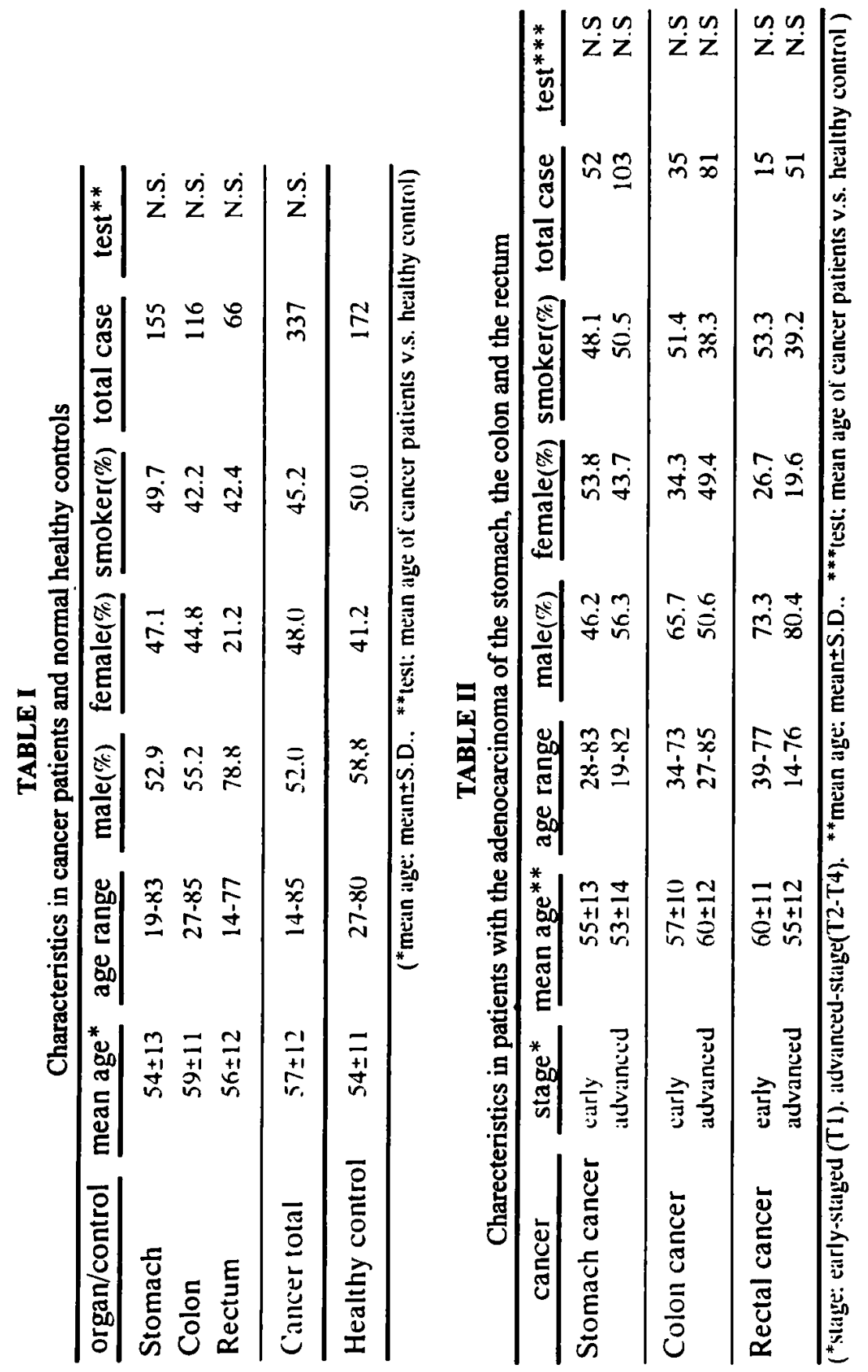


VOL. 8, NOS. $1 \& 2$ 2000
ANNALS OF Cancer Research and Therapy

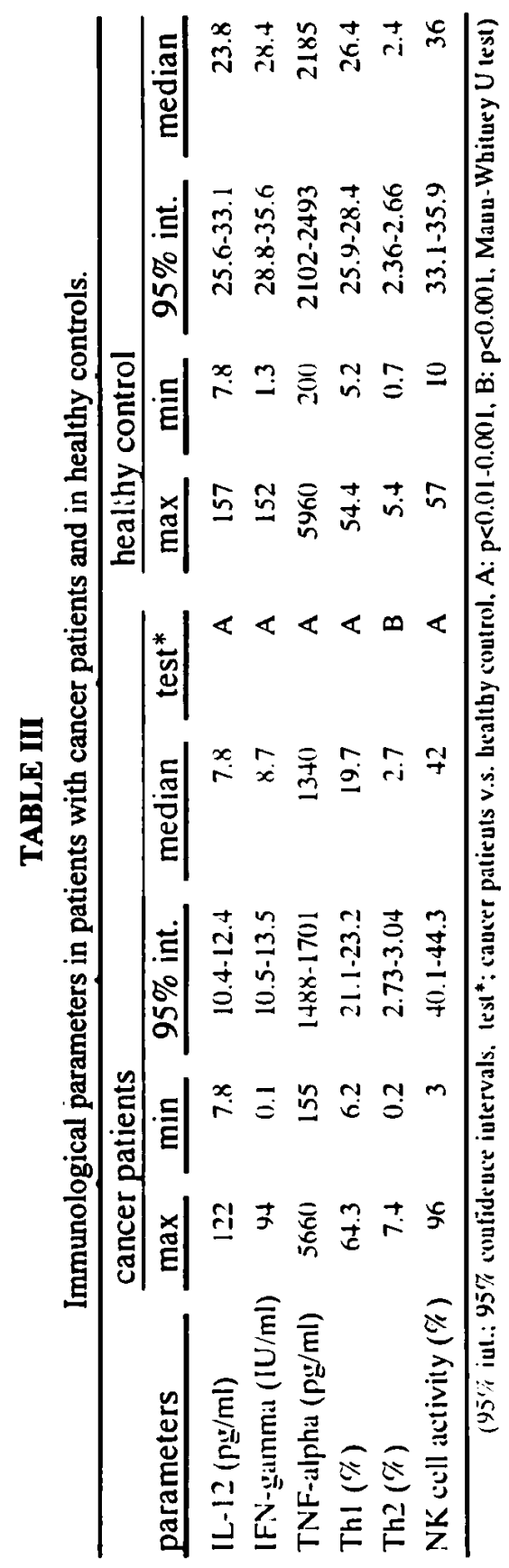




\section{TABLE IV}

Immonological parameters in cancer patients.

\begin{tabular}{|c|c|c|c|c|c|c|c|c|}
\hline cancer & parameters & Stage & $\max$ & $\min$ & $95 \%$ int. & median & test 1 & test 2 \\
\hline \multirow[t]{12}{*}{ stomach cancer } & IL-12 & early & 31.8 & 7.8 & $9.5-12.7$ & 7.8 & $\mathbf{C}$ & \\
\hline & $(\mathrm{pg} / \mathrm{ml})$ & advanced & 122 & 7.8 & $9.5-14.6$ & 7.8 & C & NS \\
\hline & IFN-gamma & early & 43.9 & 0.1 & $8.5-14.5$ & 8.45 & c & \\
\hline & $(\mathrm{IU} / \mathrm{mL})$ & advanced & 94 & 0.1 & $10.2-17.2$ & 8.8 & $\mathbf{C}$ & NS \\
\hline & TNF-alpha & early & 3340 & 210 & $1155-1594$ & 1280 & C & \\
\hline & $(\mathrm{pg} / \mathrm{ml})$ & advanced & 5660 & 150 & $1437-1810$ & 1520 & $C$ & NS \\
\hline & Thl & early & 43.1 & 9.5 & $19.9-24.6$ & 19.45 & $\mathbf{B}$ & \\
\hline & $(\%)$ & advanced & 51.4 & 8.2 & $21.4-25.6$ & 21.4 & B & NS \\
\hline & Th2 & early & 6.4 & 0.2 & $2.37-3.22$ & 2.35 & NS & \\
\hline & $(\%)$ & advanced & 7.4 & 0.2 & $2.71-3.37$ & 2.8 & B & NS \\
\hline & NK eell activily & early & 82 & 12 & $37.8-46.0$ & 40 & C & \\
\hline & $(\%)$ & advanced & 82 & 3 & $39.9-46.3$ & 43 & C & NS \\
\hline \multirow[t]{12}{*}{ colon cuncer } & IL-12 & early & 41.1 & 7.8 & $9.6-15.0$ & 7.8 & C & \\
\hline & $(\mathrm{p} \mathrm{g} / \mathrm{ml})$ & advanced & 47.9 & 7.8 & $9.8 \cdot 1.3 .4$ & 7.8 & C & NS \\
\hline & IFN-gamma & early & 60.2 & 0.4 & $7.5 \cdot 15.5$ & 10 & $C$ & \\
\hline & $(\mathrm{IU} / \mathrm{ml})$ & advanced & 78.7 & 0.2 & $9.8-15.7$ & 10.3 & C & NS \\
\hline & TNF-alpha & early & 4.340 & 240 & $1578-2346$ & 1750 & NS & \\
\hline & $(\mathrm{p} \mathrm{g} / \mathrm{ml})$ & advanced & 4290 & 240 & $1314-1766$ & 1220 & C & NS \\
\hline & Th! & early & .30 .2 & 7.1 & $15.9-20.3$ & 19.1 & C & \\
\hline & (\%) & advanced & 49.2 & 6.2 & $19.8-2.3 .9$ & 20.3 & C & NS \\
\hline & Th2 & early & 5.3 & 0.9 & $2.20-3.02$ & 2.2 & NS & \\
\hline & (\%) & advanced & 5.7 & 0.4 & $2.58-3.11$ & 2.8 & NS & NS \\
\hline & NK cell activity & early & 76 & 5 & $\$ 0.2-51.8$ & $\$ 5$ & C & \\
\hline & $(\%)$ & advanced & 70 & 7 & $.36 .0-42.8$ & 39 & B & A \\
\hline \multirow[t]{12}{*}{ rectal cancer } & IL-1? & early & 29.2 & 7.8 & $6.6-14.2$ & 7.8 & B & \\
\hline & $(\mathrm{pg} / \mathrm{ml})$ & advanced & 32.4 & 7.8 & $8.4-11.5$ & 7.8 & C & NS \\
\hline & IFN-gamma & early & 32.1 & 0.6 & $4.4-15.3$ & 6.3 & C & \\
\hline & $(\mathrm{IU} / \mathrm{ml})$ & advanced & 32.1 & 0.4 & $6.6-11.2$ & 6.3 & $c$ & NS \\
\hline & TNF-alpha & early & 3950 & $2 \times 0$ & 1012.2298 & 1.370 & NS & \\
\hline & $(0,2 / n)$ & advanicu & 4200 & $2 \times 11$ & $|28+-187|$ & 1.310 & $c$ & NS \\
\hline & Thl & early & $64 . .3$ & 6.9 & 1.3.6-28.9 & 17.2 & $A$ & \\
\hline & (\%) & advanced & $64 . .3$ & 6.9 & 19.7-26.0 & 19 & $\Lambda$ & NS \\
\hline & Th? & eurly & 7.1 & 1.2 & $1.97-3.82$ & 2.4 & NS & \\
\hline & $(\%)$ & advanced & 7.1 & 1.1 & 2.49 .3 .28 & 2.7 & NS & NS \\
\hline & NK coll activily & early & ny & 21 & $.37 .01-54.2$ & 44 & B & \\
\hline & $(\%)$ & advanced & hy & 5 & $39.4-4 \times .9$ & th & ( & NS \\
\hline
\end{tabular}

(95\% int.; $95 \%$ confidence intervals, test 1 ; vs. healthy control, test 2 ; early staged vs. advance-staged, $A: p<0.05-0.01, B: p<0.01-0.001, C: p<0.001$, Kruskal-Wallis test) 
and Lengyel 1992; Trinchieri,1993; and Tripp, Kanagawa et al.,1995). APCs produce IL-12, which stimulates Thl cells (Gately, Wolitzky et al., 1992; Locksley, 1993; and Romagnani 1994) to proliferate and differentiate into effector cells, including cytotoxic $T$ cells (Gately, Desai et al., 1991), and delayed-type hypersensitivity-committed T cells (Trinchieri 1994). In the presence of IL-12, Thl cells produce IFN- $\gamma$, with which the Thl cell itself proliferates and in turn, IFN- $\gamma$ augments IL-12 production by APCs. On the other hand, Th2 cells, which are mainly involved in allergic reactions and Ig production, are dependent on APC-derived IL-1, instead of IL-12, and they produce IL-4 with which Th2 cells proliferate. Th1 cells are negatively regulated by IL-10 (D'Andrea, AsteAmezaga et al., 1993; and Young, Gartner et al., 1999) and IL-4, which are produced by Th2 cells by the mechanism of blocking macrophage-derived IL-12 production. Thus, Th1 and Th2 negatively regulate each other and are mutually inhibitory.

After implantation of tumor cells in a mouse model, Thl cells were activated to show anti-tumor responses in the presence of Thl-related cytokines. Later in the process of tumor progression, the Th1 system was down-regulated and overwhelmed by the Th2 system, which allowed tumor cells to grow (Corry, Reiner et al., 1994; Kishikawa, Song et al., 1997; and Nastala, Edington et al., 1994). Therefore, IFN- $\gamma$ and IL-12 (Brunda, Luistro et al., 1993; Mu, Zou et al., 1995; and Zou, Shimizu et al., 1992) also seem to participate in $T$ cell-mediated anti-tumor immunity. In this study we demonstrated that levels of Thl-related cytokines were lower in cancer patients than those in the control group, even in the early-stage patients, which appeared compatible with the abovementioned findings in mice. These cytokines were already down-regulated at an early stage, there being no difference between early-stage and advanced-stage patients.

IL-12 was originally found to be a cytokine that stimulates NK cells (Kobayashi, Fitz et al., 1989; Liebermann, Siegal et al., 1991; and Yago, Tukuda et al., 1998), and NK cells were found to be required for IL-12 induced anti-tumor responses in mice (Pham-Nguyen, Yang et al., 1999). In the present study, NK cell function was not impaired in cancers. The result of these studies and our data suggest that even in earlystage cancer, the Thl system is already impaired. However, this is quite different from the results of animal model reports, in which the Thl system was activated shortly after the implantation of tumors (Siders, Wright et al., 1998). 
In this study, we employed in vitro mitogenic stimulation to evaluate cytokine production and Th subset induction. In this investigation we were clearly determining the function not only of tumor-specific $T$ cell clone(s) but also of other $T$ cells. Therefore, the fact that we detected abnormal Thl functions in patients with cancer suggests that detected abnormalities were not limited to the tumor-specific Thl subset and its precursor, but also spread to other $T$ cell repertoires that would be involved in other specific cancers.

The Thl-related immune system may have been impaired in patients whose tumor cells were small in size and this may have affected the immune system, being down-regulated by a Thl-related function. Therefore, we conclude that Th1-related immune parameters might be useful immunological markers for detecting groups at high risk for cancer among subjects undergoing medical examinations.

\section{References}

Brunda M.J., Luistro L., Warrier R.R., Wright R.B., Hubbard B.R., and Murphy M. (1993). Anti-tumor and antimetastatic activity of interleukin-12 against murine tumors. J. Exp. Med. 1223-1230.

Cassatella M.A., Meda L., Gasperini S. (1995). Interleukin-12 production by human polymorphonuclear leukocytes. Eur. J. Immunol. 25:1.

Chan S.H., Kobayashi M., Santoli D., Perussia B., and Trinchieri G (1997). Mechanism of IFN-gamma induction by natural killer cell stimulatory factor (NKSF/IL-12). Role of transcription and mRNA stability in the synergistic interaction between NKSF and IL-12. J. Immunol. 148:92-98.

Corry D.B., Reiner S.L., Linsley P.S., and Losksley R.M. (1994). Differential effects of CD28-B7 on the development of $\mathrm{Th} 1$ or $\mathrm{Th} 2$ effector cells in experimental Leishmaniasis. J. Immunol. 153: 94142-94148.

D'Andrea A., Aste-Amezaga M., Valiante N.M., Max Kubin M., and Trinchieri G.(1993). Interleukin 10 (IL-10) inhibits human lymphocyte interferon gamma-production by suppressing natural killer cell stimulatory factor/IL-12 synthesis in accessory cells. J.Exp. Med. 178 31041-31048.

Gately M.K., Desai B.B., Wolitzky A.G., Quinn P.M., Dwyer C.M., Podlaski F.J. (1991). Regulation of human lymphocyte proliferation by a heterodimeric cytokine, IL-12 (cytotoxic lymphocyte maturation factor). J. Immunol. 147: 874-882.

Gately M.K., Wolitzky A.G., Quinn P.M., and Chizzonite R. (1992). Regulation of human cytolytic lymphocyte responses by inteleukin-12. Cell Immunol. 143: 127142.

International Union Against Cancer (UICC) 1997: TNM classification of malignant tumors. Edited by LH Sobin and Ch Wittekind. $5^{\text {th }}$ ed. New York. 
Kishikawa H., Song R., and Lawrence D.A. (1997). Interleukin-12 promotes enhanced resistance to Listeria monocytogenes infection of lead-exposed mice. Toxcol. Appl. Pharmacol. 147: 180-189.

Kobayashi M., Fitz L., Ryan M., Hewick R.M., Clark S.C., and Chan S. (1989). Identification and purification of natural killer cell stimulatory factor (NKSF), a cytokine with multiple biological effects on human lymphocytes. J. Exp. Med. 170: 827-845.

Liebermann M.D., Siegal R.K., Williams M.N., and Daly J.M. (1991). Natural killer stimulatory factor (NKSF) augments natural killer cell and antibody-dependent tumoricidal response against colon carcinoma cell lines. J. Surg. Res.1991; 50: 410-415.

Locksley R M. (1993). Interleukin-12 in host defense against microbial pathogens. Proc. Natl. Acad. Sci. USA 90: 5879-5880.

Mosmann T.R., Cherwinski H., Bond M.W., Giedlin M.A., and Coffman R.L. (1986). Two types of murine helper T cell clone. I. Definition according to profiles of lymphokine activities and secreted proteins. J. Immunol. 136:2348-2357.

Mu J., Zou J.P., Yamamoto N., Tsutsumi T., Tai X.G., and Kobayashi M. (1995). Administration of recombinant interleukin 12 prevents outgrowth of tumor cells metastasizing spontaneously to lung and lymph nodes. Cancer. Res. 55: 44044408.

Nastala C.L., Edington H.D., Mckinney T.G., Tahara H., Nalesnik M.A., Brunda M.J. (1994). Recombinant IL-12 administration induces tumor regression in association with IFN-gamma production. J. Immunol. 153: 1697-1706.

Ogata M., Shimizu J., Kosaka H., Maekawa R., Shimizu K., and Fujisawa H. (1986). Expression of $\mathrm{H}-2$ antigens inducibility of anti-tumor immune responses in various tumor cell clones established from methylchlolanthrene-induced fibrosarcoma. Jpn.J. Cancer Res. 77:1134-1141.

Pham-Nguyen K.B., Yang W., Saxena R., Thung S.N., Woo S.L., and Chen S. H. (1999). Role of NK and T cells in IL-12-induced anti-tumor response against hepatic colon carcinoma. Int. J. Cancer 81: 5813-5819.

Romagnani S. (1994). Lymphokine production by human $\mathrm{T}$ cells in disease states. Annu.Rev. Immunol. 12:227-257.

Sen G.C., and Lengyel P. (1992). The interferon system. J. Biol. Chem. 267: 5017-5020.

Siders W.M., Wright P.W., Hixon J.A., Alvord W.G., Back T.C., Wiltrout R.H., and Fenton R.G. (1998). T cell- and NK cell-independent inhibition of hepatic metastases by systemic administration of an IL-12-expressing recombinant adenovirus. J. Immunol. 160: 5465-74.

Trinchieri G. Interleukin-12 and its role in the generation of TH1 cells (1993). Immunol. Today 14: 335-338.

Trinchieri G. (1994). Interleukin-12: A cytokine produced by antigen-presenting cells with immuno-regulatory functions in the generation of T-helper cells type 1 and cytotoxic lymphocytes. Blood 84:4008.

Tripp C.S., Kanagawa O., and Unanue E.R. (1995). Secondary response to Listeria infection requires IFN-gamma but is partially independent of IL-12. J. Immunol. 155: 3427-3432. 
Yago T., Tukuda M., and Minami M.(1998). IL-12 promotes the adhesion of NK cells to endothelial selections under flow conditions. Clin. Immunol. 31: 346-349.

Young X., Gartner J., Zhu L., Wang S., and Brunham R.C. (1999). IL-10 gene knockout mice show enhanced Thl-like protective immunity and absent granuloma formation following Chlamydia trachomatis lung infection. J. Immunol. 162: 21010-21017.

Zou J.P., Shimizu J., Ikegame K., Yamamoto N., Ono S., and Hamaoka T. (1992). Tumor bearing mice exhibit a progressive increase in tumor antigen presenting cell function and a reciprocal decrease in tumor antigen responsive $\mathrm{CD}^{+} \mathrm{T}$ cell activity. J. Immunol. 148: 648-655.

Zou J.P., Yamamoto N., Fujii T., Takenaka H., Kobayashi M., Herrmann S.H., Wolf S.F., Fujiwara H., and Hamaoka T. (1995). Systemic administration of rIL-12 induces complete tumor regression and protective immunity: response is correlated with a striking reversal of suppressed IFN-gamma production by anti-tumor T cells. Int. Immunol. 7: 1135-1145.

COPYRIGHT ๑ $2000 \mathrm{BY}$

PJD PUBLICATIONS LIMITED, P.O. BOX 966, WESTBURY, NY 11590

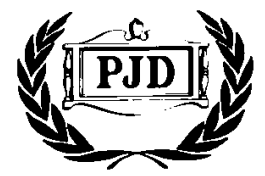

